\title{
PERSEPSI ORANG TUA TENTANG MANFAAT PAUD TERHADAP DUKUNGAN MENYEKOLAHKAN ANAK DI LEMBAGA PAUD
}

\author{
Vitasya Putri Zahrawanny ${ }^{1}$; Nila Fitria ${ }^{1}$ \\ ${ }^{1}$ Program Studi Pendidikan Guru Pendidikan Anak Usia Dini, Fakultas Psikologi dan Pendidikan, \\ Universitas Al-Azhar Indonesia, Jalan Sisingamangaraja, Kebayoran Baru, Jakarta Selatan 12110 \\ Penulis untuk Korespondensi/E-mail: nilafitria@uai.ac.id
}

\begin{abstract}
Abstrak - Persepsi adalah pengamatan seseorang tentang objek, peristiwa, atau hubungan dengan lingkungan yang diterima melalui panca indera menjadi sebuah informasi yang dipengaruhi oleh faktor internal seperti proses belajar dan faktor eksternal seperti pengetahuan. Oleh karena itu, persepsi dari setiap orang bisa berbeda-beda, sesuai dengan apa yang diterima oleh panca indra dan faktor yang memengaruhinya. Dalam penelitian ini objek atau hal yang dipersepsikan adalah manfaat Pendidikan Anak Usia Dini (PAUD), sehingga persepsi orang tua tentang manfaat PAUD dapat berbeda-beda. Persepsi yang berbeda-beda ini dapat memengaruhi bagaimana dukungan menyekolahkan anak di lembaga PAUD. Penelitian ini bertujuan untuk mengetahui pengaruh persepsi orang tua tentang manfaat PAUD terhadap dukungan menyekolahkan anak di lembaga PAUD di Kelurahan Cikasungka. Penelitian ini menggunakan metode penelitian kuantitatif dengan pendekatan survei dengan sampel penelitian berjumlah 90 orang tua yang menyekolahkan anaknya di lembaga PAUD di Kelurahan Cikasungka tahun ajaran 2019/2020. Pemilihan sampel dilakukan menggunakan teknik random sampling. Pengumpulan data dilakukan dengan menggunakan kuesioner tertutup dengan alat ukur skala likert. Teknik analisis data menggunakan analisis regresi sederhana dengan program software SPSS. Hasil penelitian ini menunjukan bahwa terdapat pengaruh antara persepsi orang tua tentang PAUD terhadap dukungan menyekolahkan anak di lembaga PAUD di Kelurahan Cikasungka dengan besaran pengaruh ( $\mathrm{R}$ square) sebesar 0,174 atau 17,4\% sedangkan 82,6\% dukungan menyekolahkan anak di lembaga PAUD dipengaruhi oleh variabel lain.
\end{abstract}

Kata Kunci: Persepsi, Manfaat, Pendidikan Anak Usia Dini, Dukungan

Abstract - Perception is a person's observation of an object, event, or relationship with the environment received through the five senses into information that is influenced by internal factors such as learning processes and external factors such as knowledge. Therefore, the perception of each person can be different, according to what is received by the five senses and the factors that influence it. In this study the object or thing perceived is the benefits of Early Childhood Education, so that parents' perceptions about the benefits of Early Childhood Education can vary. These different perceptions can influence how support for sending children to school inearly childhood education institution. This study aims to determine the effect of parents' perceptions about the benefits of Early Childhood Education (ECE) on the support of sending their children to early childhood education institution in the Cikasungka Village. This research uses a quantitative survey research method and the sample of this research is 90 parents who send their children to early childhood education institution in Cikasungka Village in the academic year 2019/2020, which are selected using a random sampling technique. Data collection techniques used by researchers using a closed questionnaire using a Likert scale measurement tool. The data analysis technique used is a simple regression analysis using the SPSS software program. The results of this study indicate that there is an influence between the Parents' Perceptions the Benefits of Early Childhood Education Against Schooling Support Children in Early Childhood Education Institutions in Cikasungka Village with the magnitude of influence ( $R$ square) of 0.174 or $17.4 \%$ while $82.6 \%$ support of sending children to school inearly childhood education institutions is influenced by other variables.

Keyword: Perception, Benefits, Early Childhood Education, Support 


\section{PENDAHULUAN}

$\mathrm{P}$ endidikan merupakan salah satu upaya dalam meningkatkan un mengembangkan generasi yang berkualitas bagi penerus bangsa. Dalam rangka mempersiapkan generasi emas yang berkualitas untuk masa depan, pendidikan merupakan salah satu hal yang penting untuk diberikan sejak usia dini. Pendidikan perlu dimulai sejak dini karena memiliki peran yang sangat menentukan, karena di usia sejak dini berbagai aspek pertumbuhan dan perkembangan anak mulai dan sedang berlangsung yang akan menjadi dasar dan penentu bagi perkembangan anak selanjutnya. Keberhasilan dalam menjalankan tugas perkembangan pada suatu masa akan menentukan keberhasilannya pada masa perkembangan berikutnya (Noorlaila, 2010: 15).

Pada dasarnya pendidikan merupakan hal yang penting dalam kehidupan, terlebih lagi pendidikan yang dimulai sejak usia dini. Hal ini dikarenakan usia dini merupakan masa keemasan (golden age). Masa dimana segala pertumbuhan dan perkembangan terjadi, sehingga pendidikan anak harus diperhatikan supaya anak dapat tumbuh dan berkembang dengan optimal. Keluarga dapat dijadikan sebagai lembagapendidikan pertama, karena dalam keluarga anak pertama-tama mengenal dan mendapatkan didikan serta bimbingan. Maka orang tua sangat berpengaruh terhadap pendidikan anak dan masa depan yang lebih baik, sehingga anak bisa sukses untuk meraih cita-citanya di kemudian hari.

Terkait hal tersebut orang tua memiliki tanggung jawab untuk memberikan pendidikan yang baik kepada anaknya. Tanggung jawab orang tua untuk memberikan pendidikan pada anak dapat berupa memasukkan anak ke suatu lembaga sekolah. Tanggung jawab ini berupa dukungan dalam menyekolahkan anaknya dalam suatu lembaga pendidikan. Dukungan yang diberikan dapat berupa memilih sekolah yang dapat memberikan fasilitas dan dapat memfasilitasi proses pembelajaran dan perkembangan anak.

Tetapi, penting dan bermanfaatnya pendidikan sejak usia dini tidak diiringi dengan dukungan orang tua untuk memberikan pendidikan pada anak sejak usia dini. Hal ini dapat dilihat dari partisipasi untuk memulai pendidikan sejak usia dini di Indonesia yang masih rendah.

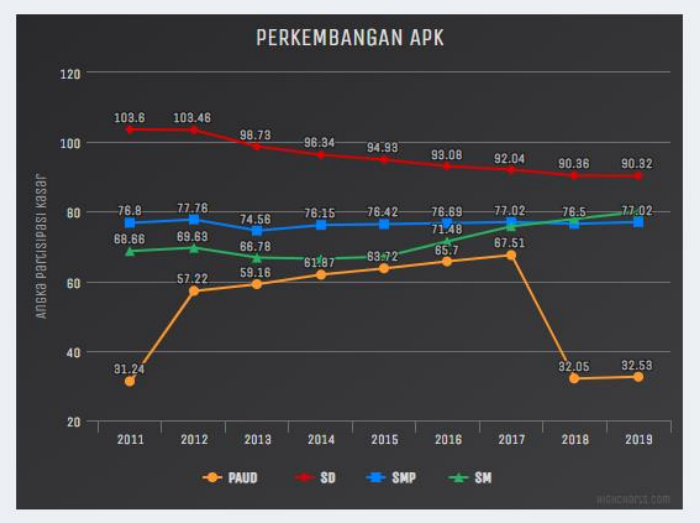

Gambar 1. Perkembangan Angka Partisipasi Kasar

Menurut data dan statistik pendidikan dan kebudayaan dari Kementerian Pendidikan dan Kebudayaan yang tercantum di atas, data Angka Partisipasi Kasar (APK) tahun ajaran 2017/2018 menunjukkan bahwa partisipasi siswa PAUD merupakan yang paling rendah dibandingkan jenjang pendidikan yang lebih tinggi. Selanjutnya menurut Ikhtisiar Data Pendidikan dan Kebudayaan (2017: 46), jumlah anak usia dini yang mendapatkan pendidikan pada tahun ajaran 2017/2018 mencapai 14.286.756 anak dari jumlah keseluruhan anak usia 3-6 tahun yang berjumlah 19.234.500 anak, itu artinya masih ada sekitar 5 juta lebih anak Indonesia yang belum terlayani kebutuhan pendidikan sejak usia dini. Banyak hal atau faktor yang memengaruhi partisipasi mengikuti PAUD masih rendah.

Berdasarkan penelitian yang dilakukan oleh Susanti pada skripsinya di tahun 2016 yang berjudul "Faktor-Faktor Penyebab Orang Tua Tidak Menyekolahkan Anaknya Di PAUD Fajar Desa Sumber Baru Kecamatan Seputih Banyak Kabupaten Lampung Tengah", disebutkan bahwa faktor-faktoryang menyebabkan orang tua tidak menyekolahkan anaknya di PAUD FAJAR adalah: (1) Tingkat pendidikan orang tua dimana masih banyaknya orang tua yang berpendidikan rendah sehingga banyak yang kurang memahami perkembangan pendidikan sehingga memengaruhi pola asuh anak; (2) Minat orang tua yang berbanding terbalik dengan keadaan ekonomidan kemauan anak; (3) Tingkat ekonomi yang masih rendah mempengaruhi orang tua untuk menyekolahkan anaknya di PAUD; (4) Lingkungan masyarakat 
dan kondisi transportasi yang kurangmendukung sehingga memengaruhi orang tua tidak menyekolahkan anaknya di PAUD FAJAR.

Masih rendahnya partisipasi masyarakat dalam mengikutsertakan anaknya dalam pendidikan sejak usia dini dipengaruhi juga oleh persepsi yang berbeda-beda. Menurut Leavitt (dalam Sobur, 2003: 445), persepsi dalam arti sempit ialah penglihatan, bagaimana cara seseorang melihat sesuatu, sedangkan dalam arti luas ialah pandangan atau pengertian, yaitu bagaimana seseorang memandang atau mengartikan sesuatu. Orang tua mempunyai pandangan yang berbeda-beda tentang manfaat PAUD. Hal ini tentu akan menjadi dorongan tersendiri bagi orang tua mengapa ia menyekolahkan anaknya di lembaga PAUD. Setiap masyarakat/ orang tua mempunyai persepsi yang berbeda mengenai manfaat pendidikan, terutama pendidikan anak usia dini.

Persepsi pada hakikatnya adalah proses kognitif yang dialami oleh setiap orang di dalam memahami informasi tentang lingkungannya, baik lewat penglihatan, pendengaran, penghayatan, perasaan, dan penciuman (Thoha, 2010: 141). Segala sesuatu yang didapat di lingkungan, baik dilihat, didengar, dihayati, dirasa, dan dicium akan diproses sebagai informasi untuk bertindak.

Rakhmat (2007: 51) menyatakan persepsi adalah pengamatan tentang objek, peristiwa atau hubungan-hubungan yang diperoleh dengan menyimpulkan informasi dan menafsirkan pesan. Rakhmat juga menambahkan bahwa persepsi memberikan makna pada stimulus indrawi (sensory stimulus). Setiap orang mempunyai kecenderungan dalam melihat objek atau peristiwa yang sama dengan cara yang berbedabeda. Perbedaan tersebut bisa dipengaruhi oleh banyak faktor, diantaranya adalah pengetahuan, pengalaman dan sudut pandangnya. Persepsi juga bertautan dengan cara pandang seseorang terhadap suatu objek atau peristiwa tertentu dengan cara yang berbeda-beda dengan menggunakan alat indera yang dimiliki, kemudian berusaha untuk menafsirkannya menjadi suatu informasi yang dapat dipahaminya.
Menurut Thoha (2010: 154), ada 2 faktor yang memengaruhi persepsi seseorang, yaitu sebagai berikut :

1. Faktor internal: yaitu berupa perasaan, sikap dan kepribadian individu, prasangka, keinginan atau harapan, perhatian (fokus), proses belajar, keadaan fisik, gangguan kejiwaan, nilai dan kebutuhan juga minat dan motivasi.

2. Faktor eksternal: yaitu berupa latar belakang keluarga, informasi yang diperoleh, pengetahuan dan kebutuhan sekitar, intensitas, ukuran, keberlawanan, pengulangan gerak, hal-hal baru dan familiar atau ketidakasingan suatu objek.

Berdasarkan beberapa definisi yang telah dijelaskan di atas, maka dapat sampaikan bahwa persepsi adalah pengamatan seseorang tentang objek, peristiwa, atau hubungan dengan lingkungan yang diterima melalui panca indra menjadi sebuah informasi, dimana melalui pengamatan tersebut seseorang mempunyai kemampuan untuk membedakan, mengelompokan, dan memfokuskan suatu objek, peristiwa atau hubungan yang dialami atau diamati. Persepsi seseorang dipengaruhi oleh 2 faktor, yang pertama yaitu faktor internal yang meliputi perasaan, sikap dan kepribadian, keinginan atau harapan, perhatian, serta proses belajar, yang kedua adalah faktor eksternal, meliputi latar belakang keluarga, informasi yang diperoleh, pengetahuan, dan hal-hal baru suatu objek. Oleh karena itu, persepsi dari setiap orang bisa berbeda-beda, sesuai dengan apa yang diterima oleh panca indra dan faktorfaktor internal atau eksternal yang memengaruhinya. Objek atau peristiwa yang dipersepsikan kali ini adalah manfaat dari PAUD.

Undang Undang Nomor 20 Tahun 2003 tentang Sistem Pendidikan Nasional Pasal 1 butir 14 menyebutkan bahwa PAUD adalah upaya pembinaan yang ditujukan kepada anak usia 0-6 tahun, yang dilakukan melalui pemberian rangsangan pendidikan yang bertujuan untuk membantu mengembangkan berbagai aspek perkembangan anak baik jasmani maupun rohani agar dapat memiliki kesiapan dalam memasuki pendidikan lebih lanjut. Selanjutnya dinyatakan pula bahwa PAUD dapat diselenggarakan pada jalur formal (Taman Kanak-kanak/ Raudhathul Athfal), jalur nonformal (Taman Penitipan Anak, Kelompok 
Bermain, dan bentuk lain yang sederajat), dan pada jalur informal (melalui pendidikan keluarga atau lingkungan).

Banyak sekali manfaat bagi anak yang masuk PAUD terlebih dahulu sebelum mereka melanjutkan ke jenjang sekolah selanjutnya (Susilo, 2016: 35-36). Manfaatnya tersebut antara lain, yaitu:

1. Hampir seluruh aspek perkembangan anak tumbuh dan berkembang lebih baik dibandingkan dengan anak yang tidak masuk PAUD.

2. Anak yang menempuh PAUD terlebih dahulu menunjukkan daya imajinasi, kreativitas, inovatif, dan produktivitas lebih tinggi dibandingkan dengan anak yang tidak menempuh PAUD terlebih dahulu.

3. Pendidikan yang diberikan sejak dini berpengaruh signifikan terhadap perkembangan otak, kesehatan, kehidupan sosial dan ekonomi, serta kesiapan anak untuk melanjutkan ke jenjang sekolah selanjutnya.

4. Mengurangi pengulangan kelas saat di kelas 1 SD dibandingkan dengan anak yang tidak masuk PAUD.

5. Anak yang mengikuti PAUD menjadi lebih mandiri, disiplin, dan mudah diarahkan untuk menyerap ilmu lebih optimal dibandingkan dengan anak yang tidak pernah mengikuti PAUD.

Dapat disampaikan bahwa manfaat bagi anak masuk PAUD adalah untuk mengembangkan seluruh aspek pertumbuhan dan perkembangan anak, dimana anak yang menempuh PAUD dapat menunjukkan daya imajinasi, kreativitas, inovatif dan produktivitas yang lebih tinggi, serta lebih mandiri dan disiplin dibandingkan dengan anak yang tidak pernah mengikuti PAUD. Tetapi perlu menjadi catatan bahwa lulus dari lembaga PAUD bukan menjadi prasyarat untuk masuk ke kelas 1 Sekolah Dasar (SD).

Persepsi atau pandangan orang tua mengenai manfaat PAUD dapat berbeda-beda, tergantung dengan apa yang diterimanya melalui panca indera dan faktor-faktor yang mempengaruhinya. Bermanfaat atau tidaknya PAUD yang dipersepsikan oleh orang tua dapat memengaruhi pemberian pendidikan berupa dukungan menyekolahkan anak di lembaga
PAUD. Sehingga dukungan yang diberikanpun dapat berbeda-beda.

Dukungan merupakan dorongan atau motivasi dari seseorang, dengan demikian motivasi adalah keadaan yang terdapat dalam diri seseorang yang mendorongnya untuk melakukan aktivitas tertentu guna pencapaian suatu tujuan (Djaali, 2012: 101). Dukungan dapat diberikan dari seseorang kepada orang lain, dalam kehidupan sosial manusia tidak dapat hidup sendiri sehingga setiap individu membutuhkan bantuan atau dukungan dari orang lain. Dukungan dapat berasal dari orang tua, keluarga, teman sebaya, maupun lingkungan sosial. Dukungan tersebut dapat berupa menyediakan sesuatu untuk memenuhi kebutuhan orang lain.

Taylor (dalam Dirgantoro, 2015: 9) menjelaskan dukungan orang tua merupakan salah satu bentuk dari dukungan sosial berupa bantuan yang dapat diberikan kepada keluarga lain berupa barang, jasa, informasi dan nasehat, yang mana membuat penerima dukungan akan merasa disayang, dihargai, dan merasa nyaman. Pada dasarnya menurut Hasbullah (2001: 41) dukungan orang tua terhadap pendidikan anaknya menyangkut dua hal pokok yaitu dukungan moral dan dukungan material.

1. Dukungan Moral. Dukungan moral dari orang tua terhadap pendidikan anaknya dapat berupa perhatian terhadap pemenuhan kebutuhan psikis yang meliputi kasih sayang, keteladanan, bimbingan dan pengarahan, dorongan, menanamkan rasa percaya diri. Dengan perhatian orang tua yang berupa pemenuhan kebutuhan psikis tersebut diharapkan dapat memberikan semangat belajar anak guna meraih suatu cita-cita atau prestasi.

2. Dukungan Material. Dukungan material merupakan dukungan berupa pemenuhan kebutuhan fisik yaitu biaya pendidikan, fasilitas belajar, alat dan buku keperluan belajar. Untuk memenuhi kebutuhan fisik tersebut tentunya berkaitan dengan status sosial ekonomi keluarga atau pendapatan di dalam keluarga itu sendiri.

Berdasarkan penelitian terdahulu yang dilakukan oleh Susanti tahun 2016 tentang faktor-faktor penyebab orang tua tidak menyekolahkan anaknya di PAUD serta permasalahan yang telah diuraikan di atas, 
membuat peneliti akhirnya memutuskan untuk melakukan penelitian mengenai Pengaruh Persepsi Orang Tua tentang Manfaat PAUD terhadap Dukungan Menyekolahkan Anak di Lembaga PAUD di Kelurahan Cikasungka dengan tujuan untuk mengetahui adakah pengaruh persepsi orang tua tentang manfaat PAUD terhadap dukungan menyekolahkan anak di lembaga PAUD di Kelurahan Cikasungka.

\section{METODE PENELITIAN}

Metode penelitian yang digunakan adalah metode kuantitatif dengan pendekatan survei. Kuantitatif adalah penelitian yang menjelaskan diawali dengan kerangka teori, pemikiran dari para ahli hingga pemecahan permasalahan untuk memperoleh pembenaran suatu penelitian. Disebut metode penelitian kuantitatif karena menurut Sugiyono (2018: 7) data penelitian berupa angka-angka dan analisis menggunakan statistik.

Penelitian metode kuantitatif dengan pendekatan survei memiliki ciri khas yaitu data yang dikumpulkan menggunakan angket atau kuesioner yang diberikan kepada responden. Kuesioner atau angket merupakan teknik pengumpulan data yang dilakukan dengan cara memberi seperangkat pertanyaan atau pernyataan tertulis kepada responden untuk dijawab (Sugiyono, 2018: 142).

Penelitian ini bertempat di lembaga PAUD formal dan non formal se-Kelurahan Cikasungka, Kabupaten Tangerang dengan waktu penelitian dilakukan selama 5 bulan dari bulan Februari-Agustus tahun 2019.

Lembaga PAUD yang menjadi tempat penelitian terdiri dari 3 lembaga yaitu; RA Generasi Qurani (Perum Taman Adiyasa Blok F7 No.51), TK Jaya (Perum Taman Adiyasa), dan TK Al Istiqomah (Perum Bukit Cikasungka Blok BFF 4), serta 3 lembaga PAUD nonformal yaitu; KB Generasi Qurani (Perum Taman Adiyasa Blok F7 No.51), KB Mutiara Bangsa (Kampung Ranca RT 09/02), dan Pos PAUD Nabilla (Perum Bukit Cikasungka Blok ADF 11 No.20). Dimana subjek penelitiannya adalah orang tua yang menyekolahkan anaknya di beberapa lembaga PAUD tersebut.

Jumlah sampel dalam penelitian ini adalah 90 responden dari sekitar 442 populasi orang tua yang menyekolahkan anaknya di lembaga PAUD di Kelurahan Cikasungka. Pengambilan sampel dalam penelitian ini menggunakan teknik Simple Random Sampling. Teknik pengumpulan data yang digunakan dalam penelitian ini adalah dengan menggunakan kuesioner.

Uji validitas instrumen menggunakan rumus Korelasi Product Moment, sedangkan untuk uji reliabilitas instrument menggunakan rumus Alpha Cronbach. Teknik analisis data yang digunakan adalah analisis regresi linear sederhana, dimana perhitungannya dibantu program SPSS. Untuk memenuhi persyaratan pemenuhan uji regresi maka perlu dilakukan uji persyaratan analisis yang meliputi uji normalitas dan uji linearitas. Uji persyaratan analisis dilakukan dengan maksud untuk memberikan gambaran tentang sejauh mana persyaratan telah dipenuhi sesuai dengan teknik analisis data yang telah direncanakan.

\section{HASIL DAN PEMBAHASAN}

\section{Karakteristik Responden}

Penelitian dilakukan kepada 90 responden di Kelurahan Cikasungka, dengan rincian karakteristik responden pada penelitian ini didominasi oleh perempuan dengan jumlah 72 responden dan laki-laki 18 responden. Pendidikan terakhir responden di Kelurahan Cikasunga didominasi oleh responden dengan tingkat pendidikan terakhir SMA sederajat. Tingkat ekonomi responden di Kelurahan Cikasungka didominasi oleh responden dengan tingkat ekonomi rendah, dimana pengkategorian pada tingkat ekonomi didasarkan pada Upah Minimum Kabupaten (UMK) di Kabupaten Tangerang yaitu sebesar Rp3.841.389, apabila responden dengan penghasilan di bawah UMK maka dikategorikan dengan responden tingkat kategori rendah, apabila penghasilan responden setara dengan UMK maka dikategorikan sebagai responden dengan tingkat ekonomi rata-rata, dan apabila penghasilan responden di atas UMK maka dikategorikan sebagai responden dengan kategori tingkat ekonomi di atas rata-rata atau tinggi. Penetapan besaran UMK berdasarkan Surat Keputusan Gubernur Banten Nomor 561/ Kep.318-Huk/2018 tentang Penetapan Upah Minimum Kabupaten/ Kota di Provinsi Banten Tahun 2019. Hasil perhitungan 
karakteristik responden disajikan pada tabeltabel di bawah ini :

\begin{tabular}{lcc}
\multicolumn{3}{c}{ Tabel 1. Jenis Kelamin Responden } \\
& Frequency & Percent \\
\hline Perempuan & 72 & 80,0 \\
Laki-Laki & 18 & 20,0 \\
\hline Total & 90 & 100,0
\end{tabular}

Tabel 2. Pendidikan Terakhir Responden

\begin{tabular}{lcc}
\hline Tingkat Pendidikan & Frequency & Percent \\
\hline SD & 14 & 15,6 \\
SMP & 16 & 17,8 \\
SMA & 41 & 45,6 \\
DIPLOMA & 6 & 6,7 \\
SARJANA & 13 & 14,4 \\
\hline Total & 90 & 100,0 \\
\hline
\end{tabular}

Tabel 3. Tingkat Ekonomi Responden

\begin{tabular}{lcc} 
& Frequency & Percent \\
\hline Rendah & 67 & 74,4 \\
Rata-rata & 23 & 25,6 \\
Tinggi & 0 & 0 \\
\hline Total & 90 & 100,0 \\
\hline
\end{tabular}

\section{Hasil Olah Data}

Deskrispi data hasil penelitian digunakan untuk melihat tingkat kategori persepsi orang tua tentang manfaat PAUD dan dukungan menyekolahkan anak di lembaga PAUD di Kelurahan Cikasungka. Berikut adalah tabel rekapitulasi intervaldan kategori persepsi orang tua tentang manfaat PAUD serta dukungan menyekolahkan anak di lembaga PAUD di Kelurahan Cikasungka.
Tabel 4. Rekapitulasi Interval dan Kategori Persepsi Orang Tua tentang Manfaat PAUD di Kelurahan Cikasungka

\begin{tabular}{cccc}
\hline Interval & Frekuensi & $\begin{array}{c}\text { Persentase } \\
(\%)\end{array}$ & Kategori \\
\hline $15-17$ & 7 & 7,8 & $\begin{array}{c}\text { Sangat } \\
\text { rendah }\end{array}$ \\
\hline $18-20$ & 58 & 64,4 & Rendah \\
\hline $21-23$ & 20 & 22,2 & Sedang \\
\hline $24-26$ & 5 & 5,6 & Tinggi \\
\hline $26-28$ & 0 & 0 & $\begin{array}{c}\text { Sangat } \\
\text { tinggi }\end{array}$ \\
\hline Total & 90 & 100,0 & \\
\hline
\end{tabular}

Tabel 5 Rekapitulasi Interval dan Kategori dukungan menyekolahkan anak di PAUD di Kelurahan Cikasungka

\begin{tabular}{cccc}
\hline Interval & Frekuensi & $\begin{array}{c}\text { Persentase } \\
(\%)\end{array}$ & Kategori \\
\hline $71-78$ & 5 & 5,6 & $\begin{array}{c}\text { Sangat } \\
\text { rendah }\end{array}$ \\
\hline $79-87$ & 37 & 41,1 & Rendah \\
\hline $88-95$ & 35 & 38,9 & Sedang \\
\hline 96,103 & 10 & 11,1 & Tinggi \\
\hline & & & Sangat \\
$103-111$ & 3 & 3,3 & tinggi \\
\hline Total & 90 & 100,0 & \\
\hline
\end{tabular}

Dari tabel tersebut diketahui bahwa persepsi orang tua tentang manfaat PAUD di Kelurahan Cikasungka berada pada kategori rendah dan dukungan menyekolahkan anak di lembaga PAUD di Kelurahan Cikasungka juga berada pada kategori rendah.

\section{Uji Persyaratan Analisis}

1. Uji Normalitas

Uji normalitas merupakan salah satu bagian dari uji persyaratan analisis data atau uji asumsi 
klasik, artinya sebelum melakukan analisis yang sebenarnya, data penelitian tersebut harus diuji kenormalan distribusinya. Keputusan uji normalitas adalah jika nilai signifikansi lebih besar dari 0,05 maka data tersebut berdistribusi normal. Sebaliknya jika nilai signifikansi lebih kecil dari 0,05 maka data tersebut tidak berdistribusi normal. Hasil perhitungan uji normalitas data pada penelitian ini yang perhitungannya dibantu dengan program software SPSS, didapatkan nilai variabel persepsi orang tua tentang manfaat PAUD memiliki nilai signifikansi sebesar 0,006 dan variabel dukungan menyekolahkan anak di lembaga PAUD memiliki nilai signifikansi sebesar 0,385 dimana hasil dari kedua variabel dinyatakan bersdistibusi normal.

\section{Uji Hipotesis}

Hipotesis yang akan diuji berbunyi "Terdapat Pengaruh Persepsi Orang Tua tentang Manfaat PAUD Terhadap Dukungan Menyekolahkan Anak di Lembaga PAUD". Untuk menguji hipotesis tersebut maka digunakan statistik uji regresi linear sederhana. Hasil dari analisis data antara variabel persepsi orang tua tentang manfaat PAUD (X) terhadap dukungan menyekolahkan anak di lembaga PAUD (Y) diperoleh model persamaan regresi sebagai berikut :

$$
\mathrm{Y}=58,726+1,498 \mathrm{X}
$$

Dengan penjelasan sebagai berikut :

$\mathrm{a}=$ angka konstan dari unstandardized coefficients. Dalam kasus ini nilainya sebesar 58,726. Angka tersebut merupakan angka konstan yang mempunyai arti bahwa jika tidak ada persepsi orang tua tentang manfaat PAUD (X) maka nilai konsistensi dukungan menyekolahkan anak di lembaga PAUD adalah 58,726 .

$\mathrm{b}=$ angka koefisien regresi. Nilainya sebesar 1,498. Angka ini mengandung arti bahwa setiap penambahan $1 \%$ persepsi orang tua tentang manfaat PAUD (X), maka dukungan menyekolahkan anak di lembaga PAUD akan meningkat sebesar 1,498.

Maka dengan demikian dapat dikatakan bahwa setiap kenaikan dalam persepsi orang tua tentang manfaat PAUD (X) akan menaikkan dukungan menyekolahkan anak di lembaga PAUD (Y) sebesar 1,498 pada nilai awal
58,726. Karena nilai koefisien regresi bernilai positif (+), maka dengan demikian dapat dikatakan bahwa persepsi orang tua tentang manfaat PAUD (X) berpengaruh positif terhadap dukungan menyekolahkan anak di lembaga PAUD.

\section{Uji Signifikansi}

Uji $\mathrm{F}$ dilakukan untuk mengetahui signifikan persamaan regresi. Jika nilai $\mathrm{F}$ hitung $>\mathrm{F}$ tabel, maka variabel independent (bebas) berpengaruh signifikan terhadap variabel dependent (terikat). Sebaliknya, jika $\mathrm{F}$ hitung < $\mathrm{F}$ tabel, maka variabel independent (bebas) tidak berpengaruh signifikan terhadap variabel dependent (terikat). Hasil perhitungan uji signifikansi yang perhitungannya dibantu program SPSS diperoleh nilai $F$ hitung sebesar 18,545 lebih besar dari $F$ tabel sebesar 3,93, sehingga dapat ditarik kesimpulan bahwa "Persepsi Orang tua tentang manfaat PAUD (X) berpengaruh terhadap Dukungan Menyekolahkan Anak di Lembaga PAUD (Y)".

\section{Uji Linearitas}

Uji Linearitas digunakan untuk melihat apakah hubungan antara dua variabel tergolong linear atau tidak. Kriteria pengujian linearitas adalah jika nilai signifikansi pada Deviation From Linearity Significant lebih besar dari taraf signifikansi 0,05 dan Fhitung lebih kecil dari Ftabel pada nilai taraf signifikansi 0,05 , maka hubungan antara variabel bebas terhadap variabel terikat adalah linear.

Hasil perhitungan uji linearitas yang perhitungannya dibantu program SPSS didapatkan nilai Deviation From Linearity Significant adalah sebesar 0,632 > 0,05 dan Fhitung sebesar 0,784 < Ftabel sebesar 1,45, maka dapat disimpulkan bahwa Ho ditolak dan Ha diterima, artinya persamaan regresi $\mathrm{Y}=$ $58,726+1,498 X$ bersifat linear.

Selanjutnya untuk mengetahui berapa besar sumbangan atau pengaruh persepsi orang tua tentang manfaat PAUD terhadap dukungan menyekolahkan anak di lembaga PAUD diketahui melalui koefisien determinasi.

\section{Analisis Determinasi}

Untuk mengetahui besarnya pengaruh persepsi orang tua tentang manfaat PAUD $(\mathrm{X})$ terhadap dukungan menyekolahkan anak di lembaga PAUD (Y) dalam analisis regresi linear 
sederhana dilakukan analisis determinasi. Hasil perhitungan uji $\mathrm{R}$ square yang perhitungannya dibantu dengan program software SPSS didapatkan nilai $\mathrm{R}$ square sebesar 0,174 . Nilai ini mengandung arti bahwa pengaruh persepsi orang tua tentang manfaat PAUD (X) terhadap dukungan menyekolahkan anak di lembaga PAUD (Y) adalah sebesar $17,4 \%$, sedangkan $82,6 \%$ dukungan menyekolahkan anak di lembaga PAUD dipengaruhi oleh variabel lain yang tidak dibahas dalam penelitian ini.

Berdasarkan hasil olah data yang telah disajikan, menunjukkan beberapa hal terkait dengan persepsi orang tua tentang manfaat PAUD dan dukungan menyekolahkan anaknya di lembaga PAUD, yaitu dari 90 responden yang merupakan orang tua dengan anak yang bersekolah di lembaga PAUD di Kelurahan Cikasungka yang dibagi menjadi 5 kategori, yaitu kategori sangat rendah, rendah, sedang, tinggi, dan sangat tinggi, menujukkan tingkat variabel persepsi orang tua tentang manfaat PAUD (X) berada pada kategori rendah, dengan jumlah responden paling banyak, yaitu berjumlah 58 responden pada jarak interval $18,00-20,00$.

Tingkat persepsi orang tua tentang manfaat PAUD di Kelurahan Cikasungka berada pada kategori rendah diperkuat dari hasil perhitungan karakteristik responden dimana pendidikan terakhir orang tua di Kelurahan Cikasungka didominasi lulusan yang masih rendah yaitu lulusan dari Sekolah Menengah Atas (SMA) sederajat, yaitu sebanyak 41 responden atau sebesar 45,6\%. Tingkat pendidikan memengaruhi tingkat pengetahuan dan proses belajar seseorang, dimana pengetahuan yang dimiliki dan proses belajar juga memengaruhi persepsi seseorang terhadap suatu objek atau peristiwa. Hal ini sejalan dengan yang dikemukakan oleh Thoha (2003: 154) bahwa ada 2 faktor yang memengaruhi persepsi, yaitu faktor internal dan faktor eksternal, dimana faktor internalnya berupa proses belajar dari individu itu sendiri, dan faktor eksternalnya adalah pengetahuan dari individu itu sendiri.

Tingkat persepsi orang tua tentang manfaat PAUD yang berada pada kategori rendah diperkuat dari latar belakang pendidikan responden yang didominasi dari lulusan SMA. Kemudian didapatkan hasil rendahnya dukungan menyekolahkan anak di lembaga
PAUD diperkuat dari hasil perhitungan karakteristik responden, dimana tingkat ekonomi dari responden pada penelitian ini didominasi oleh responden dengan tingkat ekonomi kategori sedang dengan jumlah penghasilan di bawah Upah Minimum Kabupaten (UMK) Tangerang per bulan dan jumlah responden dengan kategori tingkat ekonomi rendah sebanyak 67 responden atau $74,4 \%$ dari keseluruhan responden. Tingkat ekonomi seseorang juga berkaitan dengan dukungan dalam pemenuhan kebutuhan pendidikan anaknya. Hal ini sejalan dengan yang dikemukakan oleh Hasbullah (2001: 41) bahwa ada 2 hal pokok yang menyangkut dukungan orang tua terhadap pendidikan anaknya, yaitu dukungan moral berupa pemenuhan kebutuhan psikis dan dukungan material berupa pemenuhan kebutuhan fisik, dimana untuk memenuhi kebutuhan tersebut berkaitan dengan status sosial ekonomi keluarga atau pendapatan di dalam keluarga itu sendiri.

Hal ini menyatakan bahwa persepsi orang tua tentang manfaat PAUD mempengaruhi dukungan menyekolahkan anak di lembaga PAUD. Dapat dilihat dari hasil perhitungan pada kategori interval, menunjukkan bahwa rendahnya persepsi orang tua tentang manfaat PAUD memengaruhi dukungan menyekolahkan anak di lembaga PAUD juga rendah.

\section{SIMPULAN DAN SARAN}

Berdasarkan hasil data yang diperoleh, terdapat pengaruh pada persepsi orang tua tentang manfaat PAUD terhadap dukungan menyekolahkan anak di lembaga PAUD di Kelurahan Cikasungka dengan besaran pengaruh $\mathrm{R}$ square $\left(\mathrm{R}^{2}\right)$ sebesar $17,4 \%$.

Hasil penelitian ini memberikan informasi bahwa persepsi orang tua tentang manfaat PAUD mempengaruhi dukungan menyekolahkan anak di lembaga PAUD. Oleh karena itu, jika persepsi orang tua tinggi, maka dukungan menyekolahkan anak di lembaga PAUD juga akan meningkat. Walaupun tidak selalu dukungan menyekolahkan anak di lembaga PAUD dipengaruhi oleh persepsi orang tua tentang manfaat PAUD, dikarenakan besaran pengaruh yang dihasilkan dari perhitungan $\mathrm{R}$ square cukup kecil yaitu hanya $17,4 \%$. 
Adapun saran dalam penelitian ini adalah (1) Bagi orang tua untuk dapat menambah wawasan tentang PAUD, khususnya tentang pengertian PAUD, fungsi dan manfaat PAUD, agar tidak keliru dalam memahami pengertian, fungsi, dan manfaat dari PAUD melalui berbagai bacaan dan tayangan tentang Pendidikan Anak Usia Dini baik melalui buku, media elektronik lainnya atau mengikuti sosialisasi yang diadakan pemerintah; (2) Bagi pemerintah untuk dapat memberikan sosialisasi tentang PAUD khususnya tentang pengertian, fungsi, dan manfaat PAUD agar masyarakat tidak keliru mengenai pengertian, fungsi, dan manfaat dari PAUD, bukan hanya di kota-kota besar, tetapi juga hingga ke desa-desa terpencil yang belum tersosialisasikan pentingnya Pendidikan Anak Usia Dini; (3) Bagi peneliti selanjutnya untuk dapat dijadikan referensi dalam melakukan penelitian selanjutnya dengan menambah variabel lain yang belum diteliti.

\section{DAFTAR PUSTAKA}

Apkapm.data.kemendikbud.go.id. (2019). APK/APM KEMDIKBUD Indonesia. Jakarta:

Kemendikbud.http://apkapm.data.kemdikbu d.go.id/index.php/cberanda/apkapmsekolah ?kode wilayah $=000000 \&$ tahun $=$. Tanggal akses 15 Februari 2019

Depdiknas. (2003). Undang-Undang RI Nomor 20 Tahun 2003 tentang Sistem Pendidikan Nasional. Jakarta. Depdiknas

Dirgantoro, R. (2015). Hubungan antara dukungan orang tua dengan prestasi belajar pada siswa smk saraswati jurusan multimedia Salatiga. Salatiga. Program Studi Psikologi. Fakultas Psikologi Universitas Kristen Satya Wacana
Djaali. (2012). Psikologi pendidikan. Jakarta: PT. Bumi Aksara.

Hasbullah. (2001). Dasar-dasar ilmu pendidikan. Jakarta: Raja Grafindo Persada.

Kemendikbud. (2017). Ikhtisiar data pendidikan \& kebudayaan. Jakarta: Kemendikbud. https://www.publikasi.data.kemendikbud.g o.id . Tanggalakses 15 Februari 2019

Noorlaila. (2010). Panduan lengkap mengajar PAUD. Yogyakarta: Pinus.

Rakhmat, J. (2007). Persepsi dalam Proses Belajar Mengajar. Jakarta: Rajawali Press

Sobur, A. (2003). Psikologi umum dalam lintasan sejarah. Bandung: Pustaka Setia.

Sugiyono. (2018). metode penelitian kuantitatif, kualitatif, dan R\&D. Bandung: Alfabeta

Susanti, W.E. (2016). Faktor penyebab orang tua tidak menyekolahkan anaknya di PAUD Fajar Desa Sumber Baru Kecamatan Seputih Banyak Kabupaten Lampung Tengah. Lampung. Program Studi Pendidikan Pancasila dan Kewarganegaraan Jurusan Pendidikan Ilmu Pengetahuan Sosial. FKIP Universitas Lampung.

Susilo, S. (2016). Pedoman penyelenggaraan PAUD. Jakarta: Bee Media Pustaka

Thoha, M. (2010). Perilaku organisasi konsep dasar dan aplikasinya. Jakarta: PT Raja Grafindo Persada 